\title{
Caral-Supe y su entorno natural y social en los orígenes de la civilización
}

\author{
Ruth Shady Solís \\ Universidad Nacional Mayor de San Marcos \\ E-mail: caral@terra.com.pe
}

\begin{abstract}
RESUMEN
Iniciamos las investigaciones arqueológicas sobre los orígenes de la civilización en el Perú con una exploración en el valle de Supe en 1994 y con excavaciones en Caral en 1996. Ambas como iniciativa personal con el apoyo de un equipo de arqueólogos. Posteriormente, en 1999, ante los primeros resultados, publicados en el país y en el extranjero, la Universidad de San Marcos adicionó su apoyo económico al que venían dando las Municipalidades de Supe y de Barranca. Con el reconocimiento de Caral como sitio de interés nacional en el 2001, se creó dos años después el Proyecto Especial Arqueológico Caral-Supe (PEACS);se han intensificado las excavaciones en Caral y en otros tres sitios y se hacen trabajos de consolidación y restauración. Pero, además, contamos con un Plan Maestro y hay proyectos en ejecución con el fin de lograr que el importante patrimonio cultural de Caral sea presentado en el contexto natural y social adecuados.
\end{abstract}

Palabras clave: Civilización, ciudad, estado, complementaridad económica agropesquera, especialización laboral, estratos sociales jerarquizados.

\begin{abstract}
We began our archaeological research on the origins of civilization in Peru in 1994 with exploration in the Supe Valley and excavations in Caral in 1996; in both cases this work stemmed from a personal initiative and was supported by of a team of archaeologists. Subsequently, in 1999, in view of the first results that had been published in Peru and abroad, the University of San Marcos added its financial support to the funds already being provided by the Municipalities of Supe and Barranca. Once Caral was officially recognized as a site of national interest in 2001, two years later the Caral-Supe Special Archaeological Project (PEACS) was created; excavation work in Caral and three other sites has been intensified, and consolidation and restoration work is now under way. In addition, we have drawn up a Master Plan and there are projects currently in execution to ensure that the important cultural heritage of Caral is presented in the most appropriate natural and social context.
\end{abstract}

KeY words: Civilization, City, State, Economic complementarity, Agrofishery, Labor Specialization, Social stratus nested. 
«(...) idolo dios Guari porque este antes que ubiesse yngas y apoes quando los indios se mataban por defender sus chacaras se aparecia (...) y les repartio todas las chacaras y acequias en todos los pueblos y parcialidades y se las pirco que son las mismas que ahora siembran y que este era el que les daba las comidas y aguas» (Duviols, 1986:11,127).

\section{INTRODUCCIÓN}

Para comprender el desarrollo de Caral es necesario conocer las condiciones naturales y sociales del ámbito donde se formó la civilización más antigua de América, uno mayor, a nivel del área norcentral del Perú, en costa, sierra y selva andina en el que ha sido identificado un conjunto de asentamientos del período Arcaico Tardío; el inmediato, en el valle de Supe, en relación con los otros sitios pertenecientes al mismo período y uno central, en relación con los asentamientos ubicados en la zona comprendida entre los valles de Fortaleza y Huaura. Con este marco referencial, del área, del valle y de su zona de manejo directos, adquieren significación y verdadera dimensión los resultados de la investigación en Caral, en los aspectos social, económico y político, que presentamos en este artículo.

Desde que iniciamos las investigaciones en el valle de Supe en 1994 y, posteriormente, a partir de 1996 las excavaciones en Caral ${ }^{1}$, éstas han continuado en forma ininterrumpida, con la metodología de excavaciones de campo en extensión y de análisis multidisciplinario en gabinete. Se han hecho estudios del entorno y se han comparado los resultados de Caral con los de otros asentamientos del valle y del área en esa etapa del desarrollo. Diversos aspectos del sistema social, modos de vida y cultura, inferidos a partir de los trabajos en Caral, y de su vinculación con otros asentamientos coetáneos, han venido siendo presentados desde 1997 en sucesivas publicaciones y a través de exposiciones y muestras museológicas (Shady, 19972004). Estos resultados han sido enriquecidos con las investigaciones que simultáneamente hemos emprendido, con similar metodología, en otros tres asentamientos del mismo valle: Chupacigarro, Miraya y Lurihuasi; disponemos, así, de la información de cuatro asentamientos y contamos con mejor sustento para aproximarnos al conocimiento de la sociedad de Supe en los albores de la civilización.

\section{LOS ORÍGENES DE LA CIVILIZACIÓN: NUESTROS PLANTEAMIENTOS}

Los resultados obtenidos hasta la fecha nos permiten plantear que la sociedad de Supe vivió en asentamientos nucleados de diversos tamaños, distribuidos a lo largo

1 Tomamos el nombre de Caral de la toponimia local correspondiente al pueblo más cercano. Anteriormente, se conocía como Chupacigarro a éste y a otros tres asentamientos. 
del valle, desde el litoral hasta la terminación del valle medio; sustentados por una economía autosuficiente; cada uno con sus respectivas autoridades pero articulados en un sistema, que fomentó una dinámica esfera de interacción supralocal y contactos interregionales a larga distancia así como la formación de un gobierno centralizado.

Si bien los 18 asentamientos, que hemos reconocido en Supe del Arcaico Tardío,varían en cuanto a su extensión, número y tamaño o complejidad de sus componentes arquitectónicos (Shady et al., 2000:13-48), comparten, por otro lado, características en la composición de las construccciones y en el diseño arquitectónico de algunas edificaciones. Todos los asentamientos tienen algún tipo de construcción pública, en particular un edificio anexado a una plaza circular hundida, en asociación con plataformas y conjuntos residenciales.

Es en base a los rasgos compartidos y a las diferencias entre los asentamientos que sustentamos: 1. la población residía en asentamientos nucleados con su respectivo territorio de producción y su propio gobierno y autoridades. Esta forma de organización social y territorial, «pachaca», continuaría en el área a lo largo de la historia prehispánica. 2. Pero, asimismo, se constata que, alrededor de los 2600 a.C., los ocupantes de los asentamientos en el territorio entre el Fortaleza y el Huaura estaban integrados en un sistema social organizado y jerarquizado, con una «zona central» en el valle medio inferior de Supe, donde Caral habría sido el eje de irradiación social y cultural más destacado de la época.

A nivel del área norcentral, el prestigio de Caral se extendió por el espacio entre El Santa por el norte y el Chillón por el sur, tanto en las regiones de costa como de sierra y selva andina. La información cultural y temporal disponibles sugiere que la influencia del sistema social de Supe fue avanzando progresivamente y hacia los 2200 a.C ya había alcanzado por el sur a los constructores del Paraíso en el valle del Chillón. Cabe señalar, sin embargo, que los asentamientos del área norcentral (con excepción del Paraíso, que se construye al final del período) se diferencian de los de Caral-Supe en cuanto a su menor extensión o tamaño, al menor número de componentes arquitectónicos, complejidad y volumen constructivo, además de los rasgos propios de los respectivos modos de vida y culturas de sus habitantes; lo primero indicaría un mayor desarrollo en «la zona central» de Caral, donde habría estado la sede más destacada del sistema social y de mayor prestigio en el área norcentral en los albores de la civilización.

Sobre la base de los hallazgos en los asentamientos del Arcaico Tardío del área de algunos elementos culturales compartidos ya se había reconocido que ellos participaron en una esfera de interacción, que fue denominada «tradición Kotosh» (Burger y Salazar, 1980) pero no se tenían evidencias suficientes para evaluar la magnitud y relevancia que ésta había alcanzado.

Los resultados que se van obteniendo de las investigaciones en Caral indican, asimismo, que la sociedad de Supe produjo conocimientos avanzados en ciencia y 
tecnología; construyó las primeras ciudades planificadas del nuevo mundo y sentó las bases estructurales de lo que sería el sistema social y de gobierno en los Andes Centrales.

La antigüedad de este proceso, entre 2900 y 2000, está sustentada en los 42 fechados radiocarbónicos obtenidos en Caral, Chupacigarro y Lurihuasi; y se refuerza al señalar, comparativamente, que los asentamientos del valle de Supe estuvieron habitados casi al mismo tiempo que las ciudades sumerias de Mesopotamia o cuando se construyó la pirámide de Sakara o las posteriores pirámides de Gizeh en Egipto. Pero a diferencia de las sociedades del viejo mundo, como Mesopotamia, Egipto e India, que tuvieron entre ellas relaciones de intercambio de bienes y conocimientos, que les permitieron aprovechar de las experiencias del conjunto, el proceso peruano se dio en total aislamiento no sólo de otras sociedades del viejo continente sino también del nuevo mundo, pues se adelantó en, por lo menos, 1500 años al de Mesoamérica, el otro centro de civilización prístina de América.

\section{PUEBLOS Y CULTURAS DEL ÁREA NORCENTRAL Y SU MAYOR DESARROLLO}

Aun cuando el poblamiento del territorio del Perú se produjo alrededor de los 12000 años con actividades de apropiación de los recursos naturales en los diversos parajes de la costa y sierra de los Andes, como indican las evidencias arqueológicas de Lauricocha, Toquepala, Junín, en la sierra o de Paiján, en los desiertos del litoral occidental, hubo distintos procesos culturales en relación con las condiciones naturales del medio habitado, que son muy diversas en los Andes Centrales. Alrededor de los 8000 años se habían conformado asentamientos sedentarios de pequeñas aglomeraciones, cuyas actividades de subsistencia ya incluían a la agricultura. Se ha identificado a cazadores-agricultores en las zonas altoandinas; agricultorescazadores en los valles de la sierra; pescadores, recolectores de moluscos y agricultores en la costa, etc. (Shady 1995:49-61). Aparte de poseer modos de vida y culturas distintivos, estas poblaciones tenían diferentes ritmos de desarrollo. Hacia los 5000 años sólo en una parte del Perú, en el área norcentral, confluyeron condiciones sociales, culturales y naturales para el surgimiento de la civilización.

Los nueve valles de la vertiente occidental del área: Santa, Casma, Huarmey, Fortaleza, Pativilca, Supe, Huaura, Chancay y El Chillón están geográficamente conectados entre sí a través de la meseta altoandina de donde nacen sus respectivos ríos. La misma meseta los vincula también hacia el oriente con las cuencas del Marañón y el Huallaga, puertas de ingreso a la amazonía. En esta área, asî geográficamente articulada, que comprende regiones de costa, sierra y selva andina, han sido identificados asentamientos de variadas dimensiones con arquitectura pública y doméstica:

En la costa: El Paraíso en el valle El Chillón (Quilter et al 1991), Río Seco en el litoral de Chancay (Wendt, 1964), Bandurria en el litoral de Huaura (Fung, 1988), 
Áspero en el litoral de Supe (Feldman, 1980), Caral y otros en el valle de Supe (Shady, 1997a, 2000a, b, 2003), Las Haldas en el litoral de Casma. En la sierra: La Galgada en el Tablachaca-Santa (Grieder et al., 1988), Huaricoto en el Callejón de Huaylas (Burger y Salazar-Burger, 1980). En la selva andina: Kotosh en la cuenca del Huallaga (Izumi y Sono, 1963; Izumi y Terada, 1972) y Piruro en la cuenca del Marañón (Bonnier y Rozenberg, 1988). La información arqueológica disponible permite inferir que ellos no eran exclusivamente santuarios o centros religiosos sino más bien asentamientos organizados con edificaciones residenciales y públicas, donde se realizaban actividades domésticas, económicas, administrativas, políticas, religiosas, sociales y culturales. La conjunción en estos asentamientos de unidades domésticas con edificios públicos para la realización de múltiples funciones revela autosuficiencia, cierta especialización laboral y un ordenamiento político. Ellos estuvieron sustentados en la producción de excedentes de sus habitantes, todo lo cual hizo posible, asimismo, su participación en las redes de interacción que se tendieron en el área entre regiones y entre cuencas. Compartieron productos, bienes manufacturados, elementos arquitectónicos, conocimientos y participaron en determinadas ceremonias religiosas y ritos. La ubicación geográfica de CaralSupe en el medio de esta área con producciones diversas, comunicada por el mar en la costa, por la meseta altoandina en la sierra y por los ríos de la Amazonía en la selva y articulada interregionalmente en dirección vertical en cortas distancias; así como su capacidad de acumulación de excedentes proveniente de una economía complementaria agrícola-pesquera, fue estratégica para las interacciones con poblaciones asentadas en zonas ecológicas diferentes, también con producciones excedentarias, poseedoras de experiencias adaptativas diversas así como de bienes distintivos.

Por todo lo indicado, consideramos que la creciente complejización social de Supe debe ser tratada en el marco de las condiciones naturales descritas para el área norcentral y de la situación social de las poblaciones que habitaban en las varias regiones y cuencas durante el Arcaico Tardío: en la región costeña; en la región adyacente de la sierra, en el Callejón de Huaylas y el Callejón de Conchucos; y en las vertientes orientales, en las cuencas del Marañón y del Huallaga (figura 1a).

Entre estas sociedades, la de Supe pudo sintetizar en su beneficio los logros de experiencias adaptativas diferentes y supo aprovechar el excedente productivo del área. Los 18 asentamientos con arquitectura pública identificados a lo largo de 45 kilómetros en el valle de Supe, un valle de pequeña extensión, con escasas tierras y un río de régimen irregular, seco la mayor parte del año, difícilmente hubieran sido construidos sobre la base de la productividad obtenida únicamente por sus habitantes. La cuantiosa inversión de trabajo en obras monumentales y su permanente remodelación habrían sido sustentadas por la producción de las poblaciones de los otros valles del área, que las autoridades políticas del valle supieron captar. La extensión de los asentamientos principales de Supe, entre 40 y 80 hectáreas 
frente a las 11 o 13 hectáreas de los asentamientos más extensos de los otros valles, expresa una marcada diferencia en cuanto a la capacidad de manejo económico e inversión de sus ocupantes.

\section{ANTECEDENTES DE LA INVESTIGACIÓN}

A pesar de su cercanía a Lima, la ciudad capital del Perú, y de conocerse que Supe contenía numerosos sitios arqueológicos, este valle no había sido suficientemente investigado, quizás porque se había asumido sin mayores evidencias que los espectaculares volúmenes arquitectónicos estaban afiliados culturalmente al período Formativo, del cual ya se tenía información proveniente de valles vecinos. Debido a su complejidad arquitectónica, estos sitios no habían sido correlacionados con los resultados obtenidos desde la década de los setenta en Áspero, en Puerto Supe, que ya era conocido en el medio arqueológico por su arquitectura y antigüedad desde las investigaciones de Feldman y los sugerentes planteamientos de Moseley (1975).

Previamente, en 1940, Kosok en un importante estudio sobre diversos valles de la costa había visitado el de Supe y descrito algunos aspectos de Caral, incluyendo una impactante foto aérea sobre un sector de la ciudad. Cabe resaltar en este autor su planteamiento pionero, no suficientemente valorado, acerca del destacado desarrollo alcanzado por las poblaciones costeñas (Kosok, 1965:219). Por esos años, en 1941, Áspero fue reconocido por Willey y Corbett, quienes lo correlacionaron con los sitios Formativos de El Faro y Ancón (Willey y Corbett, 1954:21-23); años después, en 1971, Willey y Moseley, revisitaron Áspero, entre varios sitios de la costa, que por esos años ya habían sido identificados como pertenecientes al Arcaico Tardío, como Unidad I en el valle de Asia y Río Seco de León en Chancay. Esta información les permitió identificar los montículos con plataformas escalonadas, y sugerir que ellos podían pertenecer al Arcaico Tardío o Precerámico. Pero sólo a partir de las excavaciones de Feldman en ese mismo año en Áspero se obtuvo información sobre el contenido cultural y fechados para ubicar a este sitio en el período Arcaico Tardío del proceso cultural peruano. El autor atribuyó la arquitectura monumental de Áspero al trabajo corporativo de varias unidades domésticas, bajo la coordinación de un grupo dirigente; organización a la que caracterizó como jefatura corporativa. Sin embargo, no hubo una perspectiva del sitio como conjunto, no se excavaron las unidades domésticas y, tampoco, fue vinculado con los otros asentamientos del valle de Supe, que mostraban mayor extensión y complejidad arquitectónica (Feldman, 1980, 1985, 1987, 1992). Por ello, en las tres décadas siguientes no destacó la importancia de Supe y del período Arcaico Tardío en la formación de la civilización, aun cuando hubo las sugerentes interpretaciones de Moseley sobre la importancia del recurso marino, que suscitó la polémica en torno al rol que habían tenido el recurso marino y la 

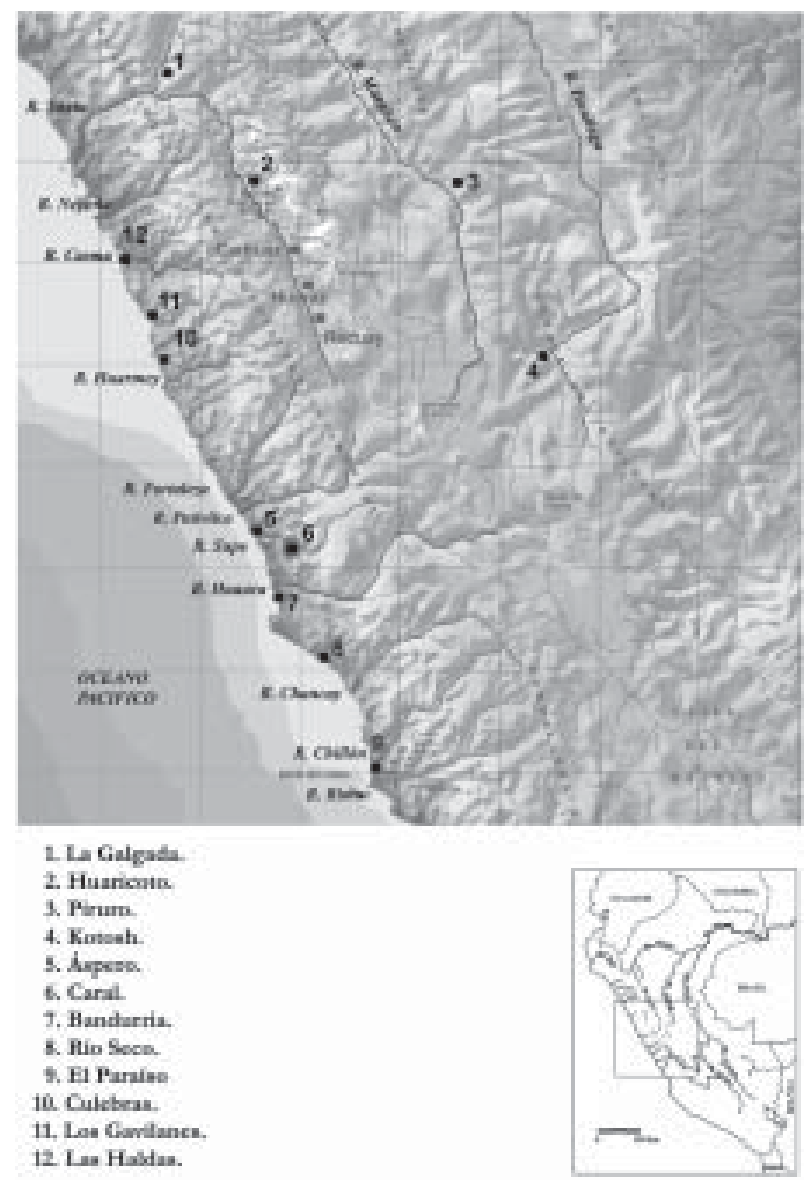

FIGURA 1a: Asentamientos del Arcaico Tardío en cuencas y regiones de costa, sierra y selva andina del área norcentral del Perú.

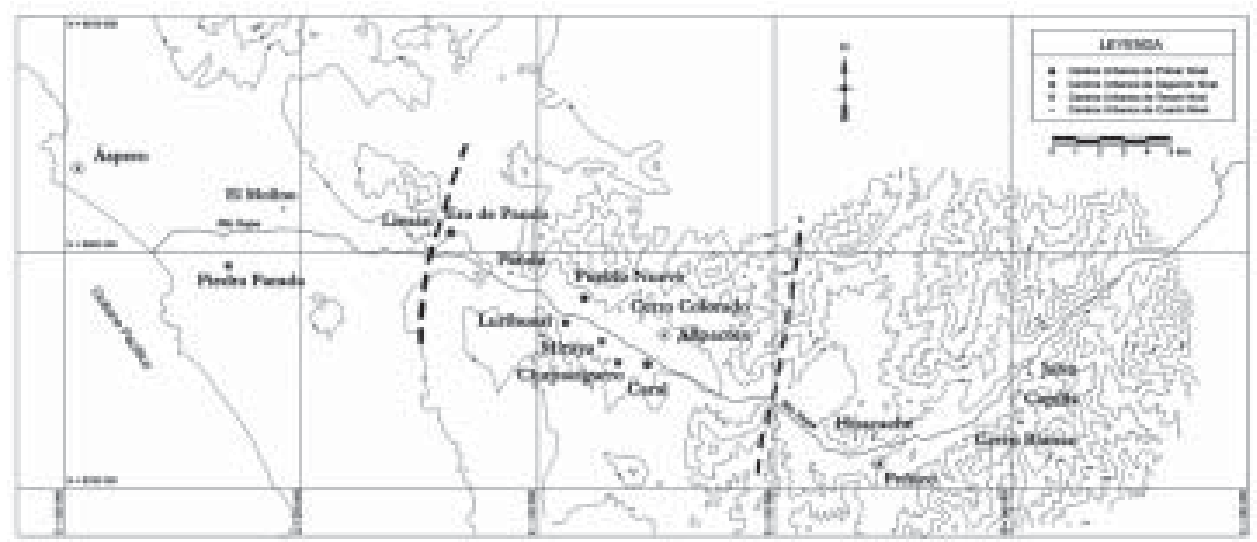

FIGURA 1b: Asentamientos del Arcaico Tardío identificados en el valle de Supe. 
actividad pesquera frente a la actividad agrícola en el desarrollo civilizatorio andino (Moseley, 1975; Raymond, 1981; Wilson, 1981).

Otras intervenciones aportaron información sobre algunos aspectos de la arqueología del valle de Supe, como los cateos y trincheras excavados en Caral por Engel (1987:82); el catastro de casi un centenar de sitios arqueológicos pertenecientes a diversos períodos, efectuado por Williams y Merino (1979) o los sugestivos estudios y sondeos realizados por Zechenter en Supe (1988), al señalar las diferencias estacionales y de recursos naturales entre las ecozonas y sugirir un patrón de subsistencia complejo para los períodos Arcaico Tardío y Formativo, basado en la explotación de un conjunto diverso de recursos. Más recientemente, la prospección arqueológica conducida por nosotros a lo largo del valle bajo y medio de Supe en 1994-1995 (Shady et al., 1995: 49-61) identificó los asentamientos pertenecientes al Arcaico Tardío, determinó sus características, parecidos y diferencias y planteó interpretaciones preliminares sobre el patrón de asentamiento y el sistema social. Pero ninguna de estas aproximaciones tuvo las evidencias contextualizadas para evaluar la importancia y significación de la sociedad de Supe y del período Arcaico Tardío en los orígenes de la civilización hasta que comenzamos las excavaciones en Caral en 1996 (Shady, 1997a, b).

\section{LA INVESTIGACIÓN ARQUEOLÓGICA EN SUPE Y LA ELECCIÓN DE CARAL}

Si bien en 1994 iniciamos la investigación en el valle de Supe mediante una prospección arqueológica y dos años después habíamos identificado la recurrencia de determinados rasgos arquitectónicos en, por lo menos, 18 asentamientos, ubicados a lo largo del valle (Shady et al., 2000: 13-48; 2003: 51-91), no teníamos indicadores arqueológicos para su afiliación cultural y temporal. Por eso, en 1996 decidimos efectuar excavaciones en uno de esos asentamientos y elegimos Caral, en base a cinco criterios: la ausencia de alfarería en la superficie del sitio, la extensión de éste, su diversidad arquitectónica con varios conjuntos domésticos y edificios públicos, la distribución ordenada de los edificios que indicaba una previa organización espacial y la monumentalidad de por lo menos siete construcciones elevadas de las 32 que se apreciaban en el sitio. Después de dos meses de trabajo en seis sectores diferentes del asentamiento tuvimos las evidencias arqueológicas suficientes para evaluar que estábamos en un sitio del Arcaico Tardío, a pesar de su complejidad arquitectónica (Shady, 1997 a; 1997 b); y que estos resultados cambiaban los conocimientos que hasta entonces se tenían sobre los orígenes de la civilización.

\section{EL TERRITORIO HABITADO POR LA SOCIEDAD DE SUPE}

El valle de Supe está en el centro del área norcentral del Perú, en las vertientes occidentales por donde discurre el río desde sus nacientes hasta su desembocadu- 
ra en el Océano Pacífico, luego de un recorrido de $92 \mathrm{~km}$ de longitud. A lo largo de su curso, el río cambia abruptamente de dirección, primero va de noreste a suroeste desde sus nacientes hasta La Empedrada en el valle medio superior, desde allí enrumba al noroeste hasta el mar. El valle es estrecho, de $1.5 \mathrm{~km}$ de ancho, limitado por la cadena de cerros que lo encierra por sectores y está conformado por depósitos aluviales de arena, arcillas, limos, gravas y conglomerados. El río Supe tiene un régimen muy irregular con marcadas diferencias entre sus descargas, una máxima de 49,44 m3/seg (que en algunos años puede llegar a $60 \mathrm{~m} 3 / \mathrm{seg}$ ) y una media anual de $1,52 \mathrm{~m} 3 / \mathrm{seg}$; pero, en cambio, cuenta con permanente agua subterránea y con los ríos Pativilca y Fortaleza forma un sistema de valles interrelacionados por canales y caminos tradicionales.

Los asentamientos humanos del Arcaico Tardío se encuentran en la mitad inferior del valle de Supe, espacio donde se distinguen cuatro zonas: litoral y lomas; valle bajo; valle medio inferior y valle medio superior, cada una separada de las otras por condiciones geográficas y con sus respectivos recursos.

\section{ASENTAMIENTOS HUMANOS Y MANEJO DEL VALLE DE SUPE} DURANTE EL ARCAICO TARDÍO

A pesar de las condiciones del valle de Supe, escasas tierras y régimen irregular del río, hubo durante el Arcaico Tardío un mínimo de 18 asentamientos poblacionales, entre el litoral y los primeros $45 \mathrm{~km}$. Todos estos sitios contienen conjuntos residenciales y también edificios públicos; y más del 50\% posee alguna obra de arquitectura monumental (figura 1b). En base al estudio comparativo de los asentamientos reconocidos mediante la prospección de superficie y de las excavaciones que venimos realizando en cuatro de ellos: Caral, Chupacigarro, Miraya y Lurihuasi, planteamos la siguiente forma de asentamiento y de organización social:

1. Distribución de los asentamientos en el valle: Los asentamientos identificados ocupan cuatro zonas ecológicas: uno en el litoral (1859,75 ha), Áspero; dos en el valle bajo ( 9214,5 ha), uno en la margen derecha, El Molino y uno en la margen izquierda, Piedra Parada; 10 en el valle medio inferior (8472 ha) seis en la margen derecha, Limán, Era de Pando, Pando, Pueblo Nuevo, Cerro Colorado, Allpacoto y cuatro en la margen izquierda, Lurihuasi, Miraya, Chupacigarro y Caral; cinco en el valle medio superior (7334,5 ha), cuatro en la margen izquierda, Peñico, Cerro Blanco, Capilla y Jaiva y uno en la margen derecha, Huacache. Como se puede apreciar, la zona del valle medio inferior, que no es la más extensa, concentra, sin embargo, el mayor número de asentamientos, 10 de un total de 18. Es, además, interesante señalar un aparente ordenamiento en la ubicación de los asentamientos; están en número similar en ambas márgenes del río, nueve en la margen derecha y nueve en la margen izquierda; distribución que respondería a un patrón dual, como también se da en el interior de cada uno de los sitios que estamos excavando. 
2. Espacio ocupado: Los asentamientos poblacionales fueron ubicados en las terrazas de los conos de deyección perpendiculares al valle; éste fue reservado para los campos de cultivo. Cada asentamiento incluía el espacio construido, en el cual ubicaban las viviendas y los edificios públicos, y la porción de tierras del fondo del valle y de las terrazas aluviales, demarcada por canales de riego principales. Es posible que la distribución del agua ya estuviera regulada.

3. Extensión de los asentamientos: Los asentamientos varían en tamaño: A) de 80 a 55 ha: Era de Pando (79,74), Caral (66,0), Pueblo Nuevo (55,01); B) de 45 a 30 ha: Miraya (43,0), Lurihuasi (37,8), Chupacigarro (37,4), Piedra Parada $(33,5)$; C) de 25 a 15 ha: Allpacoto (23,10), Peñico $(22,05)$, Áspero $(15,0)$; D) de 10 a 5 ha: Huacache $(7,59)$, El Molino $(6,96)$, Jaiva $(4,20)$; E) de menos de 5 ha: Pando $(1,95)$, Cerro Colorado $(0,98)$, Cerro Blanco $(0,80)$, Limán $(0,48)$, Capilla $(0,16)$. De ellos, tres asentamientos destacan por su extensión: Era de Pando, Caral y Pueblo Nuevo, con el 46,07\% del área total construida en el valle; le siguen en segundo lugar otros cuatro asentamientos: Miraya, Lurihuasi, Chupacigarro y Piedra Parada con el 34,82\% de la superficie total construida. Estos dos grupos tienen el 80,89\% del área construida. Es interesante que ambos se ubican mayormente en la zona media inferior. Los otros tres grupos ocupan el 13,80\%, 4,30\% y $1 \%$, respectivamente. De la comparación se infiere que 11 asentamientos de los

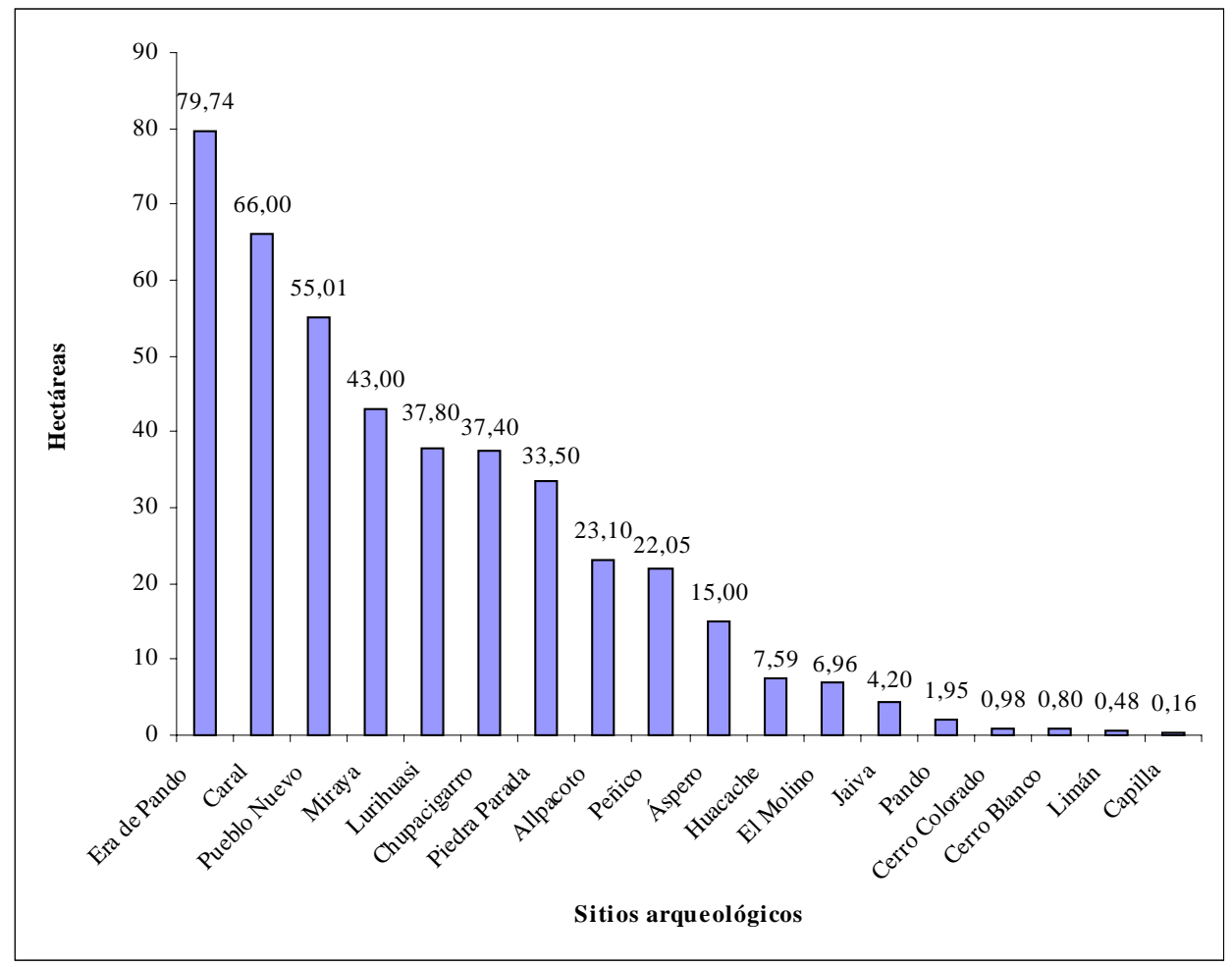


18 tienen sólo un 19,11\% del área construida. Estos resultados indican una distinción marcada entre los asentamientos; sugerimos que ella se debería a diferencias socioeconómicas, funcionales y de jerarquía social significativas entre los pobladores de las cinco clases de asentamientos (Tabla 1).

4. Inversión de trabajo en las construcciones públicas: El cálculo realizado sobre la cantidad y volumen de las estructuras de cada asentamiento permite hacer el siguiente ordenamiento: grupo 1: Pueblo Nuevo (28,99\%), Caral (27,31\%); grupo 2: Miraya (12,85\%), Era de Pando (8,54\%), Lurihuasi (7,04\%); grupo 3: Allpacoto (3,76\%), Peñico (3,12\%), El Molino (2,99\%); grupo 4: Piedra Parada $(1,67 \%)$, Áspero $(1,64 \%)$; grupo 5: Chupacigarro $(0,87 \%)$, Huacache $(0,57 \%)$; grupo 6: Cerro Blanco $(0,30 \%)$, Cerro Colorado $(0,12 \%)$, Jaiva $(0,10 \%)$, Pando $(0,07 \%)$, Limán $(0,05 \%)$, Capilla $(0,001)$. Esta información indica que el grupo 1 donde se encuentran Caral y Pueblo Nuevo concentra el 56,30\% del total de fuerza de trabajo invertida. Le sigue el grupo 2, integrado por Miraya, Era de Pando y Lurihuasi, con una inversión de $28,43 \%$ del total, que representa la mitad del grupo anterior. El tercer y cuarto grupo, compuesto por cinco asentamientos, detentan el 13,18\% del total. Es decir una cuarta parte del trabajo invertido en el primer grupo de asentamientos. Finalmente, la diferencia es muy notoria entre aquellos y los grupos quinto y sexto pues éstos, a pesar de estar integrados por ocho asentamientos, apenas exhiben el 2,08\% del total de la fuerza de trabajo invertida. Es importante resaltar la concentración de más de la mitad del total de fuerza de trabajo invertida en sólo dos asentamientos: Pueblo Nuevo y Caral. El segundo grupo de asentamientos representa un poco más de la cuarta parte del total de la fuerza de trabajo invertida. Entre estos dos grupos se hallan los cinco principales asentamientos del valle de Supe: Caral, Pueblo Nuevo, Miraya, Lurihuasi, y Era de Pando, de los cuales destacan Caral y Pueblo Nuevo, tanto por su extensión, complejidad como por la fuerza de trabajo invertida en sus construcciones. Es interesante que ambos se encuentren en el valle medio inferior, en la margen izquierda y derecha, respectivamente.

5. Zona de ubicación: Los indicadores señalan que los centros urbanos más extensos y complejos se encuentran concentrados en el valle medio inferior; ésta fue la zona central de mayor poder, bienestar y prestigio de la sociedad de Supe. A lo largo de unos seis kilómetros de esta zona se encuentran siete asentamientos con arquitectura monumental, tres en la margen derecha: Pueblo Nuevo, Cerro Colorado, Allpacoto, y otros cuatro en la margen izquierda: Lurihuasi, Miraya, Chupacigarro y Caral. Esta habría sido «la zona central», justamente ubicada en un espacio estratégico para la comunicación con los valles laterales vecinos. De los siete asentamientos, cuatro pertenecen a los grupos A y B de mayor extensión, así como a los grupos 1 y 2 de mayor inversión de trabajo. Esta zona es intermedia entre la zona del valle bajo y el litoral, proveedora de los recursos de mar, y la del valle medio superior, al Este, donde se encuentra la otra concentración de asentamientos pero de menor extensión y monumentalidad fue el centro del siste- 
ma. Los del valle medio inferior se articulan con la parte alta de los otros valles vecinos y, en particular con la meseta altiplánica desde donde se facilita la interacción con habitantes de otros valles, en la amplia extensión del área norcentral.

6. Comunicación: Las distancias entre los asentamientos ubicados en las diferentes zonas del valle es de 7,5 a $10 \mathrm{~km}$ y en el interior de una misma zona es de 2,6 a 4 km, a excepción de la «zona central» en el valle medio inferior donde la distancia entre asentamientos es de 1 a $2,6 \mathrm{~km}$.

7. Seguridad: El valle medio inferior está encerrado por la misma configuración morfológica de la cordillera y esto le da un espacio controlable. Lo separa del valle bajo la conjunción de los cerros que forman una garganta a la altura del sitio denominado Liman, pasada la cual se abre otra vez el valle y después nuevamente es cerrado por otra conjunción de cerros alrededor del sitio de Las Minas. Entre ambas gargantas se halla «la zona central» con sus asentamientos.

8. Vías o rutas de intercambio: Los asentamientos más extensos están cerca de vías de acceso a los valles vecinos, en quebradas que van en dirección perpendicular al valle. Los centros urbanos de la «zona central», ubicados en la margen derecha, se vinculan a través de la quebrada de Allpacoto con los valles de Pativilca y Fortaleza; y aquellos de la margen izquierda, como Caral, Chupacigarro y Lurihuasi salen a diversas zonas ecológicas de los valles de Huaura y de Chancay. Igualmente, en el valle medio superior tienen ubicación estratégica los centros urbanos de Peñico, para la articulación de la sierra de Supe y su entorno colindante con el valle de Huaura, y el centro de Huacache, para la comunicación entre las dos zonas del valle medio de Supe con los poblados de la sierra de Pativilca y Fortaleza. Hacia la costa, Era de Pando articulaba a los asentamientos del litoral y los valles bajos de Supe, Pativilca y Fortaleza; mientras que Piedra Parada lo hace con el valle bajo y el litoral de los valles de Supe y Huaura. Esta selección del territorio en relación con rutas de tránsito indica la importancia del intercambio entre poblaciones asentadas en zonas ecológicas con recursos y bienes diferenciados.

9. Jerarquización: El patrón de asentamientos de Supe no muestra un sistema de asentamientos que haga suponer un ordenamiento jerarquizado lineal como ha sido descrito para otras áreas del mundo bajo un sistema político integrado (Wright y Johnson, 1975: 267-289), como se esperaría en un Estado territorial. En base a los indicadores mencionados para Supe se puede distinguir en el valle dos concentraciones de asentamientos, una principal, de primera categoría, ubicada en el valle medio inferior y otra menor, con asentamientos mayormente de cuarta categoría, en el valle medio superior. Pero, además de estas dos concentraciones hay algunos otros asentamientos de segunda importancia, distribuidos en el valle bajo; y uno de tercera en el litoral. Se hace evidente que no sólo hay variables políticas que explican este ordenamiento sino sociales, económicas y de mercado.

Por otro lado, los rasgos arquitectónicos recurrentes y compartidos por la mayoría de sitios, aún cuando sean a diferentes escalas indican que ellos tenían determina- 
das funciones similares. Los asentamientos serían unidades sociales autosuficientes y multifuncionales, donde se efectuaban actividades políticas, administrativas y religiosas. Aun cuando mantuvieron esta identidad y funciones, los asentamientos habrían sido integrados, en un período medio del Arcaico Tardío, a un sistema económico complementario conducido por un Estado prístino. Un modelo intermedio entre las ciudades-estado y el estado territorial. Este modelo de organización se extendería en el Perú Prehispánico y perduraría aún durante el imperio Inca.

Los rasgos arquitectónicos similares a los del valle de Supe, que se encuentran en los asentamientos de los valles de Pativilca y Fortaleza, indican que las poblaciones de los tres valles estuvieron estrechamente articuladas, tanto en la zona del valle bajo como en las del valle medio; no obstante, como se ha indicado, el valle de Supe contiene los asentamientos más extensos y complejos, y debió ser el asiento principal del poder y de mayor prestigio. Estos tres valles habrían constituido el territorio donde tuvo su directa aplicación el sistema social y político de Supe. Sin embargo, la influencia de esta civilización se extendió también a toda el área norcentral ya señalada.

\section{LA CIUDAD SAGRADA DE CARAL}

Caral, ubicada a $182 \mathrm{~km}$ al norte de Lima y a $23 \mathrm{~km}$ desde el litoral, está asentada sobre una terraza aluvial desértica, en el valle medio inferior de Supe, a $350 \mathrm{msnm}$ En esta zona, el río pasa casi a nivel del valle con peces y camarones en la temporada de lluvias en la sierra; estaba contenido en ambas márgenes por el monte ribereño, un paisaje de bosque enmarañado y casi inexpugnable con gran variedad arbórea y arbustiva, como sauce, caña brava, carrizo, cola de caballo, etc. y animales, venados, roedores, aves, del cual quedan pequeños relictos. Esta zona cuenta, además, con los espacios cultivables del fondo del valle, de 1 a 1,5 km de ancho; con las terrazas aluviales, pobladas con guarangos y otras especies, también cultivables mediante irrigación; y con las tierras inundadas u «oconales», donde crecen totoras y juncos. Si bien el río está seco en la mayor parte del año, esta zona del valle dispone de una rica napa freática, aprovechada en las actividades domésticas como también en la irrigación de los campos cultivados.

El espacio construido de Caral se encuentra, sin embargo, en un ambiente desértico, por encima del valle, a unos $25 \mathrm{~m}$, rodeado de cerros rocosos y dunas, aislado de los campos de cultivo de los cuales lo separa un denso bosque de guarangos.

\section{Aspectos sociales y culturales de la ciudad}

Caral ocupa unas 66 ha y comprende una zona nuclear, con 32 estructuras públicas, además de varios conjuntos residenciales, y una zona en la periferia, que limita con las terrazas de guarango y el fondo del valle, donde se construyeron varios conjuntos de viviendas (figura 2). La disposición de las estructuras arquitectónicas 
indica un ordenamiento espacial de acuerdo a un diseño planificado de la ciudad antes de su construcción. En éste se tuvieron en cuenta criterios importantes de la organización social, como los estratos sociales jerarquizados y las divisiones simbólicas de los linajes: matrilineales-patrilineales, originarios-advenedizos, reflejadas en dos mitades: alta y baja, derecha e izquierda. A estos criterios se le sumaron otros, astronómicos, asociados, también, con determinadas deidades del panteón religioso; y funcionales: políticos, administrativos, económicos, ocupacionales, residenciales y de mercado.

Si bien no hay murallas defensivas en torno a la ciudad, éstas fueron construidas en el interior de ella para separar algunos edificios o recintos de acceso muy privado.

En el espacio del núcleo, las edificaciones están distribuidas en dos grandes mitades: Caral alto, donde se pueden apreciar los volúmenes piramidales más destacados, uno de ellos con una plaza circular hundida; y Caral bajo, una mitad con estructuras públicas de menores dimensiones, entre las que destaca, sin embargo, un edificio que tiene anexada la más grande plaza circular hundida de la ciudad. Esta organización espacial responde a la división dual tradicional andina de Hanan y Hurin.

\section{La mitad alta de Caral}

En la mitad alta de la ciudad todas las construcciones han sido ubicadas alrededor de un gran espacio abierto o plaza, que tuvo también funciones públicas, de tipo político, económico y manufacturero. Se pueden distinguir dos grandes subespacios: uno, al oeste, conformado por los conjuntos piramidales, que hemos denominado la Pirámide Mayor y su plaza circular, la Pirámide Central, la Pirámide de la Cantera y la Pirámide Menor (fig. 2 a); el otro hacia el Este constituido por la Pirámide de la Galería y la Pirámide de la Huanca, con un monolito hincado en el espacio entre ambas (fig. 2 b). Además de las estructuras mencionadas se encuentra en el lado sur de esta mitad alta, a todo lo largo de la terraza que la separa de la mitad baja, un extenso conjunto residencial distribuido en forma ordenada en varios subconjuntos (sector A). Pero, también, cada una de las estructuras piramidales están asociadas a dos o tres residencias, ubicadas en su entorno (fig. 3). Un mausoleo saqueado se halla hacia la periferia, al Este de la mitad alta (Shady y Gonzales, 2000: 2-9; 2003: 229-235).

Por su ubicación, tamaño, volumen constructivo y por la asociación con la plaza circular destaca la Pirámide Mayor como el principal edificio público de la ciudad (sector E).

\section{La mitad baja de Caral}

En este ámbito de la ciudad la distribución de las construcciones es diferente a la otra mitad pues éstas se encuentran alineadas en un eje este-oeste sobre una terraza baja, pero las fachadas de los edificios ya excavados están en dirección a la mitad alta. Los edificios, en general, son de menores dimensiones y no se encuentran estructuras piramidales altas ni medianas sólo pequeñas pero tiene un 

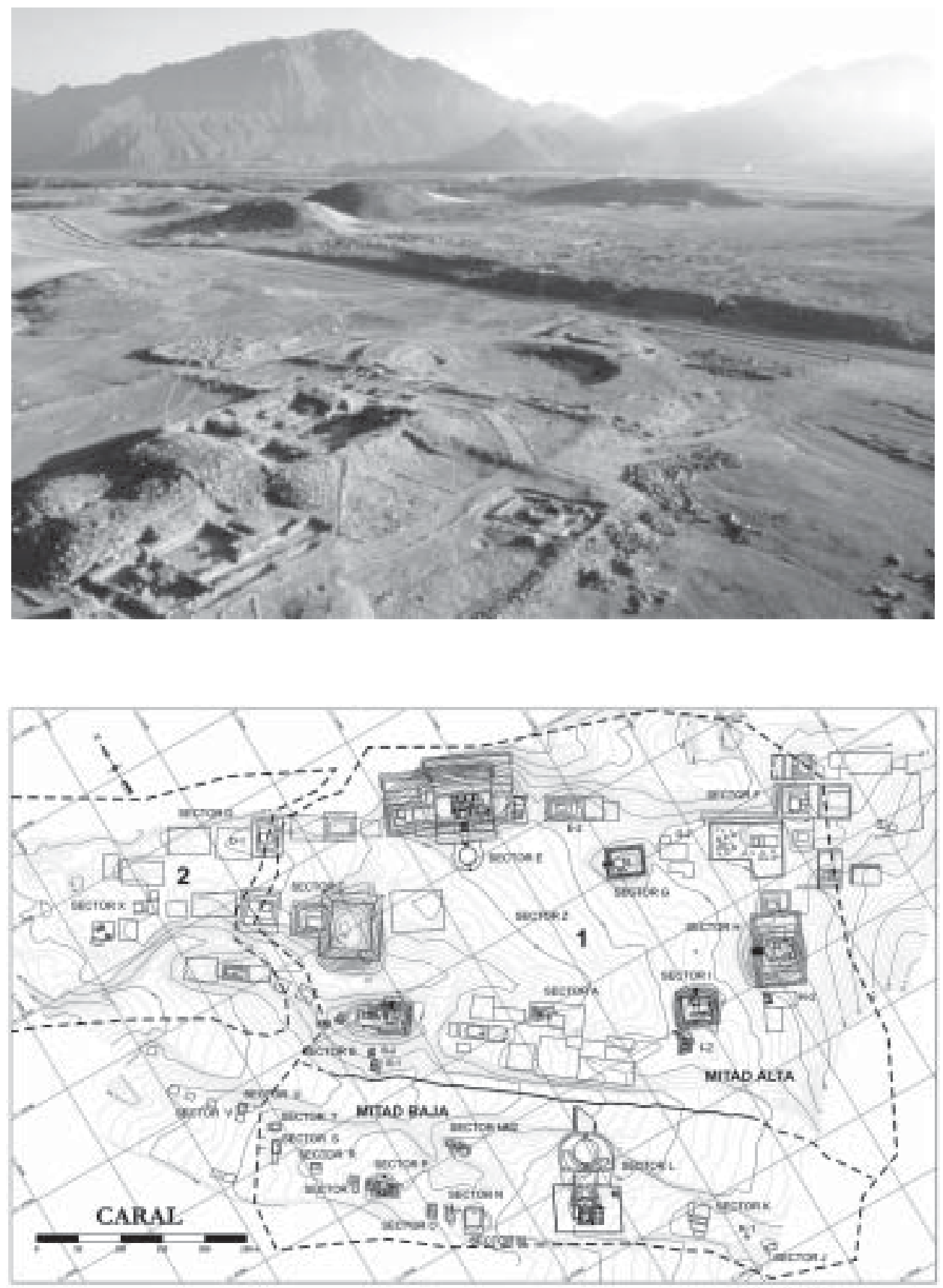

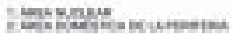

FIGURA 2: El espacio construido de Caral y su organización dual.

(Foto: George Steinmetz). 
conjunto arquitectónico especial, el denominado Templo del Anfiteatro, justamente por estar conectado a la plaza circular hundida más grande de la ciudad (sector L). Esta mitad también contiene un conjunto residencial (sector NN2), algunas unidades domésticas al lado de cada edificio público, talleres (sector $\mathrm{K}$ ) y un mausoleo saqueado en la periferia sur.

\section{Concepción arquitectónica de la ciudad de Caral}

Los 42 fechados radiocarbónicos indican que la ciudad estuvo funcionando a través de un milenio, entre 2900 y 2000 a.C., y los edificios contienen, asimismo, las evidencias de esta prolongada ocupación con sucesivos períodos de construcción y remodelación. Se han distinguido grandes períodos de construcción y enterramiento de los edificios; pero, además, entre cada uno de estos períodos sucesivas fases de remodelación arquitectónica o de cambios menores, lo que hace un promedio de 20 a 25 fases constructivas por cada monumento o unidad doméstica. Cada período está diferenciado del anterior por algunos elementos del estilo y de la técnica constructiva, materiales y por el color de la pintura aplicada a las paredes. Se conservó, sin embargo, el diseño general, relacionado con la funcionalidad del edificio pero sobre todo con la memoria social que reforzaba la identidad cultural y le daba a la sociedad la percepción de continuidad y seguridad (Hodder y Cessford 2004: 17-40). Sugerimos que las actividades relacionadas con los cambios mayores y con los cambios menores o remodelaciones estuvieron concordadas con ciclos astronómicos y con eventos sociales de gran significación.

Todas las edificaciones de la ciudad, por lo menos a partir del período Medio, alrededor de los 2600 a.C., hasta donde ha llegado nuestra investigación en la mayoría de edificaciones excavadas, muestran similares períodos constructivos y el mismo diseño, estilo, materiales y técnica arquitectónicos; por tanto, se puede inferir que estas obras debieron ser ejecutadas bajo un ordenamiento planificado, a cargo de autoridades, articuladas por un sistema político centralizado.

Han sido excavados los siguientes espacios contruidos:

\section{- Los edificios públicos}

En los períodos Medio y Tardío del largo funcionamiento de la ciudad se construyeron edificaciones piramidales de diverso tamaño, con determinada orientación estelar y bajo un similar diseño arquitectónico: un eje de ordenamiento interno, marcado por la escalera central, que conduce desde la base a la cima y la divide en dos cuerpos, cada uno de los cuales tiene una serie de terrazas superpuestas en forma escalonada, contenidas por muros de piedra. Hacia los lados del cuerpo principal se agregaron otros cuerpos o alas siguiendo un modelo escalonado, usando ángulos rectos y monolitos en las esquinas. Todos los edificios de la mitad alta presentan su fachada hacia el espacio abierto central.

Por la similitud en el diseño y en el estilo arquitectónico así como por el contex- 

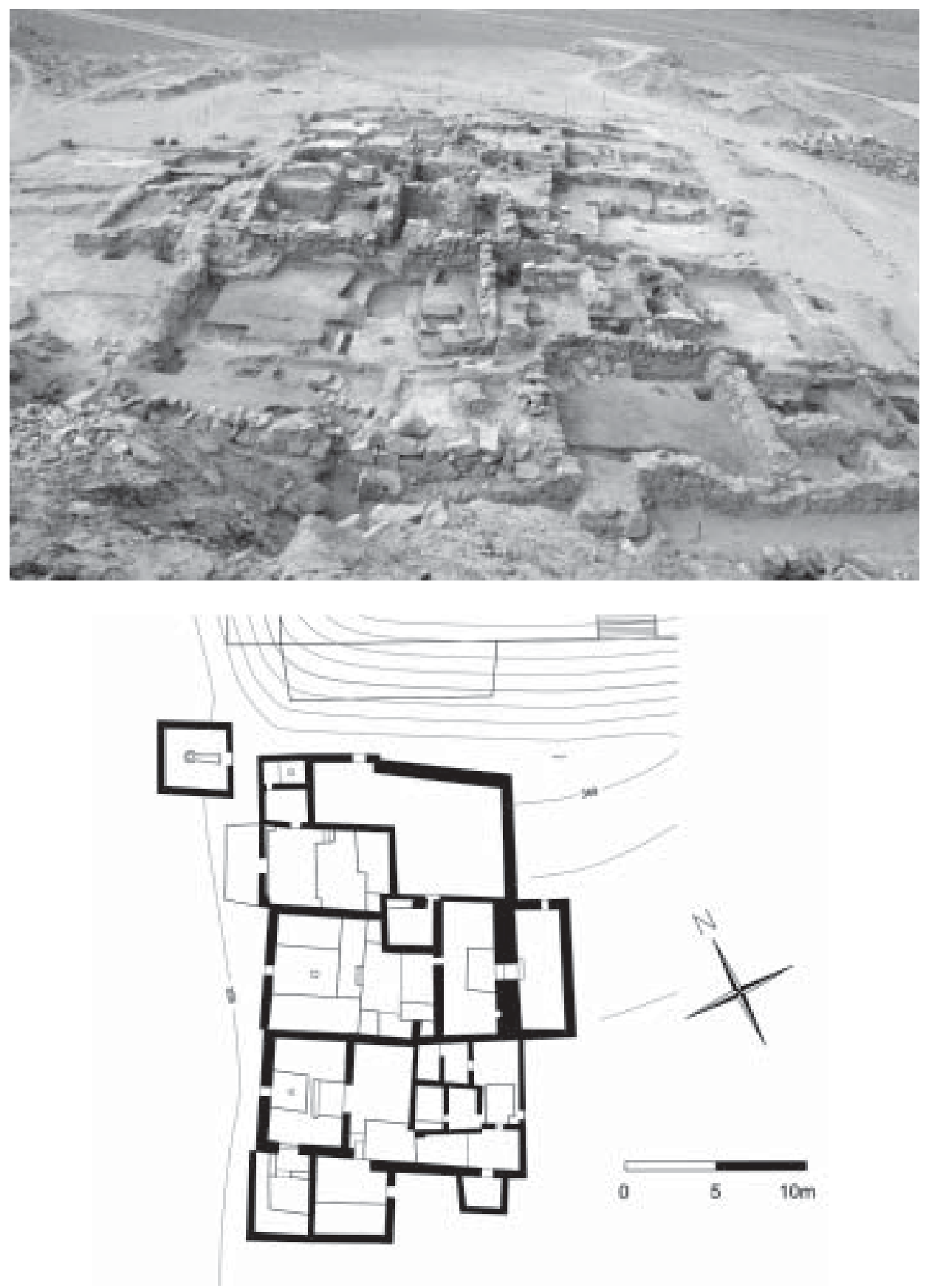

FIGURA 3: Dos unidades multifuncionales, vinculadas con los funcionarios de la «Pirámide de la Huanca». 
to de los materiales recuperados en los varios componentes excavados se ha inferido que estos edificios fueron construidos en los mismos períodos y que en sus ambientes se realizaron similares funciones múltiples: religiosas, políticas, económicas y administrativas. Sin embargo, las diferencias que ellos muestran entre sí, en cuanto a ubicación dentro de la ciudad, extensión y volumen, cantidad de componentes y contextos especiales, podrían indicar distinciones de poder entre sus autoridades o gestores así como otras de índole social, que todavía no logramos probar. Estamos trabajando con la hipótesis que estos edificios sirvieron como un calendario urbano, vinculado con la celebración de fiestas, marcadas en relación con determinados astros, identificados con deidades del panteón supano. Calendario coordinado también con la conducción de las actividades laborales.

En las construcciones más destacadas utilizaron la piedra; otros edificios tuvieron recintos con paredes de palos y cañas entrabadas, construidas sobre las terrazas contenidas con muros de piedra. En el período Tardío se generalizó el uso de bloques de piedra cortados, entrabados con mortero de arcilla y «pachillas»o piedras de menores dimensiones. Las paredes llevaron, por igual, enlucidos de arcilla y pintura de color blanco, amarillo ocre, amarillo, rojo o blanco, según los períodos constructivos de la ciudad.

\section{- Las plazas públicas}

En la ciudad se realizaron concentraciones públicas con diferentes participantes y con fines distintos en diversas clases de espacios: dos abiertos y otros dos construidos formalmente. Los dos espacios abiertos se encuentran en la mitad alta de la ciudad en asociación con los dos subconjuntos de edificios públicos, uno al oeste, el más grande, adonde confluyen todas las fachadas de los edificios (fig. 2a); y otro al Este, en relación con los dos edificios vinculados con un monolito, denominado «Huanca» (fig. 2b). Ambos espacios muestran huellas de los postes de tiendas temporales y sirvieron para la instalación de ferias en algunos períodos del calendario festivo. Estas reuniones habrían sido masivas y acudirían grupos de comerciantes y peregrinos desde diferentes lugares del área norcentral.

En cambio, las plazas construidas están en cada una de las mitades de la ciudad y forman parte de la estructura arquitectónica más destacada de ellas: la Pirámide Mayor en la mitad alta y el Templo del Anfiteatro en la mitad baja. Tuvieron diferente uso, en concordancia con la función del edificio al que estaban asociadas.

La plaza circular de la Pirámide Mayor consiste en un espacio hundido, de 21,5 $\mathrm{m}$ de diámetro, delimitado por dos murallas circulares paralelas que formaron una plataforma circular elevada, a 3,0 m de altura del piso interno. Las escaleras de acceso están presididas cada una por dos grandes monolitos parados y uno central, de posición desconocida. La escalera norte de la plaza llega hasta la escalera central de la estructura piramidal (fig. 4) (Shady et al., 2000:2-25). 

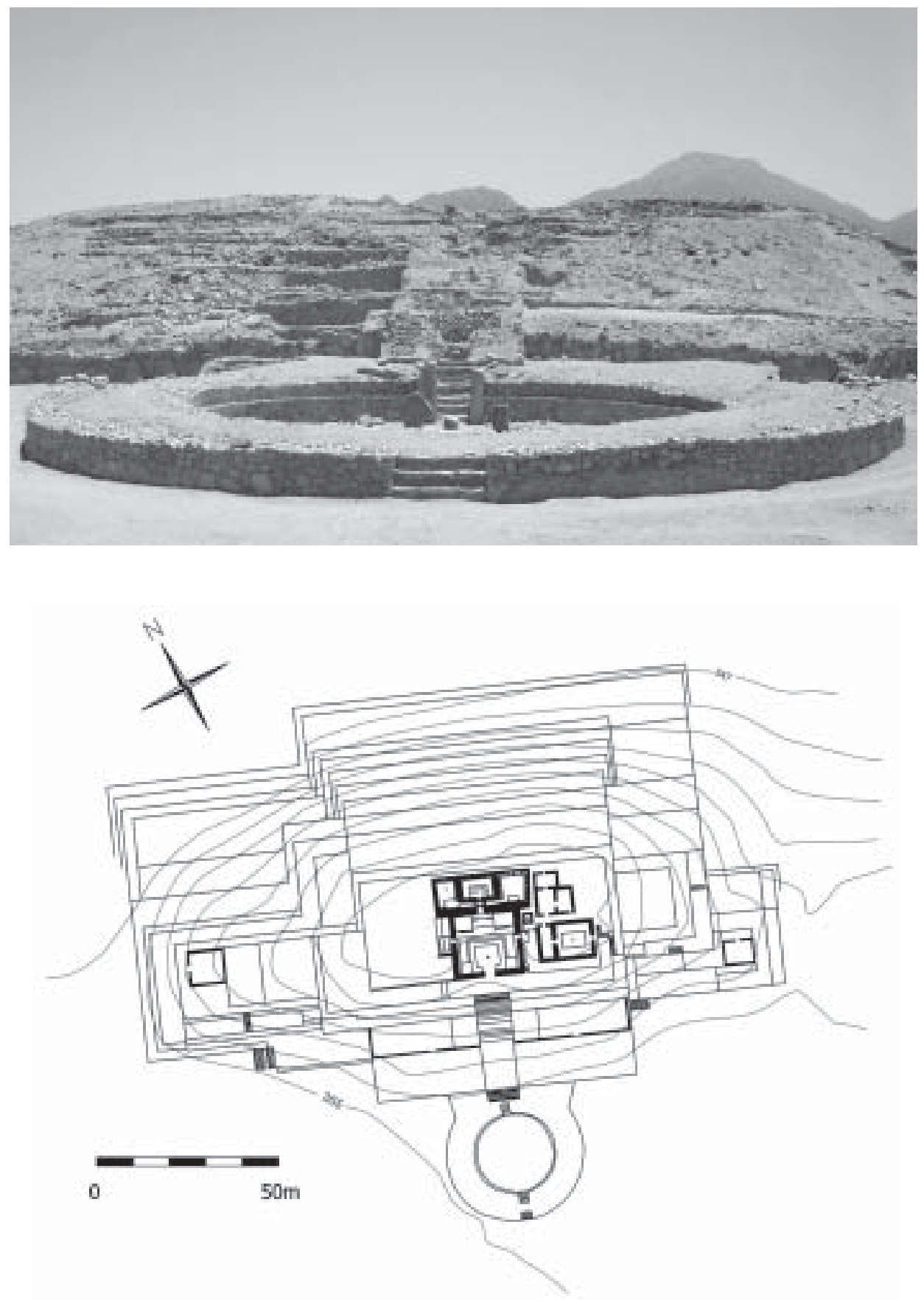

FIGURA 4 : El complejo Arquitectónico de la Pirámide Mayor y su plaza circular. 
La plaza circular hundida del Templo del Anfiteatro tiene dos escalinatas de acceso, ubicadas en el eje central, al que se alinea también el vano de ingreso al edificio piramidal. Se diferencia de la otra plaza por sus mayores dimensiones, 30 m de diámetro; carece de los monolitos pero en cambio se recuperó de ella, en el lado suroeste superior un conjunto de 32 flautas; en el lado Este un conjunto de 38 cornetas; y del centro de la plaza varias vasijas de mate, principalmente botellas pequeñas. Presenta, además, una gradería semicircular en la mitad superior (figs. 5 y 6 ).

Estas dos plazas comparten rasgos arquitectónicos, en la forma circular y hundida con dos escaleras de acceso alineadas en el eje del respectivo templo pero también muestran diferencias en cuanto a ubicación, dimensiones, algunos elementos formales y contextos. Se puede inferir que en ellas se realizaron actividades ceremoniales relacionadas con la de los edificios a los que estuvieron anexadas.

\section{- Las unidades residenciales multifuncionales}

En la ciudad hay varios sectores residenciales, que contienen conglomerados de unidades domésticas; éstos varían en cuanto a ubicación, contexto ambiental, dimensiones, técnica y materiales constructivos; y, al igual que los edificios públicos muestran sucesivos cambios a través del tiempo. En el período antiguo las paredes tuvieron soportes de madera entretejidos con caña brava (Gynerium sagitattum), revestidos con argamasa de barro y arcilla, pintadas; en el período Tardío fueron construidas con piedras cortadas de granodiorita. En los lados externos de las viviendas se depositaron los desechos domésticos; en el lado posterior están las piedras quemadas y los hoyos donde se cocieron alimentos bajo la modalidad de «pachamanca» o de piedras calientes. Las unidades residenciales comparten una serie de componentes y en ellas se efectuaban actividades tanto domésticas como de manufactura, sociales y rituales.

Hemos distinguido las siguientes clases de unidades residenciales:

1. El Conjunto residencial Mayor, conglomerado de unidades domésticas, dispuesto en un ordenamiento espacial en la mitad alta de la ciudad, subdividido en subconjuntos, separados entre sí por espacios abiertos, todavía no bien definidos. Las fachadas están dirigidas hacia los edificios públicos (sector A).

2. El Conjunto residencial Menor, de la mitad baja de la ciudad, acondicionado sobre una terraza aluvial al norte de los edificios públicos. El tamaño de las viviendas es comparativamente más reducido que en el conjunto residencial de la mitad alta de la ciudad, de la cual se diferencia también por las menores dimensiones del conglomerado. Esto permite interpretar que sus ocupantes constituían un grupo más reducido y tenían un estatus de menor jerarquía que los habitantes de la mitad alta (sector NN2).

3. El Conjunto residencial de la Periferia está conformado por varios subconjuntos o islotes ubicados a lo largo de la terraza que colinda con el valle. Las 

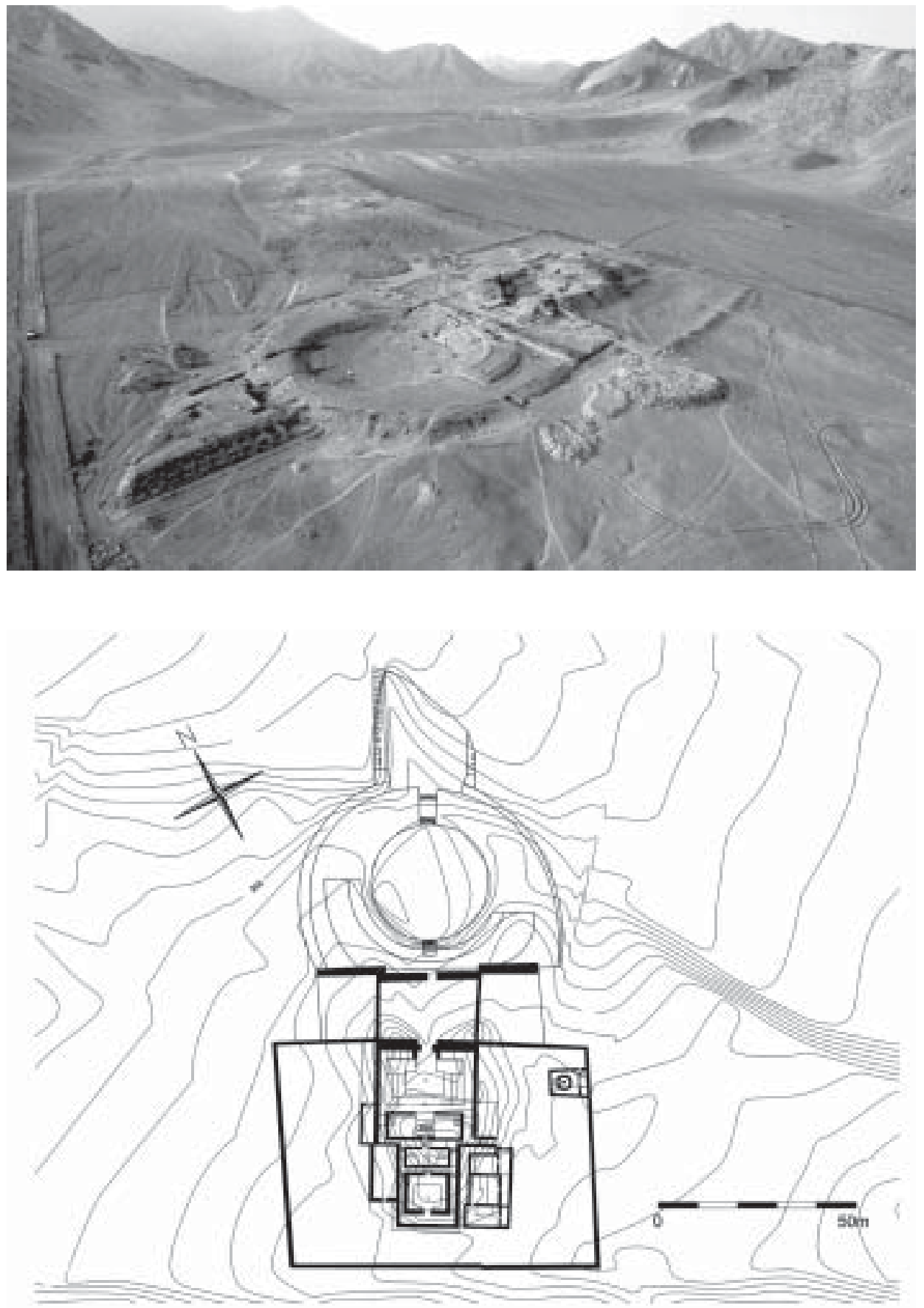

FIGURA 5 : El complejo Arquitectónico del «Templo del Anfiteatro». (Foto: Walter Wust). 
unidades domésticas son más pequeñas y su construcción se adecuó a la topografía del lugar. El material utilizado es muy similar al de los otros sectores. Por su ubicación y su menor tamaño y formalidad se puede interpretar que sus ocupantes pertenecieron al estrato social de menor estatus, quienes constituyeron la fuerza laboral más importante de la ciudad (sector X).

4. Las unidades residenciales de elite se encuentran en torno a cada uno de los edificios públicos con los cuales estuvieron vinculados $\mathrm{y}$, aunque muestran un tamaño variado, en general son de mayores dimensiones que las unidades domésticas de los otros sectores. Por la ubicación, el tamaño, el material constructivo utilizado y el contenido, se ha interpretado que estas viviendas pertenecieron a un grupo social de mayor estatus, relacionado con el funcionamiento de los edificios piramidales.

\section{TALLERES DE ESPECIALIZACIÓN ARTESANAL}

Se han identificado dos en el extremo este de la mitad baja de la ciudad. Excavamos uno, conformado por tres recintos cuadrangulares. En los pisos se hallaron pequeñas oquedades selladas con una capa de arcilla, que contenían cuentas de crisocola, cuarzo lechoso, cristal de roca, Spondylus y opérculos. Junto a ellas se encontraron desechos de talla así como herramientas de piedra y hueso. Estos recintos eran usados como talleres de producción artesanal para el suministro de artículos suntuarios (fig.7).

\section{SISTEMA ECONÓMICO DE LA SOCIEDAD DE SUPE}

Se ha recuperado en Caral ingentes cantidades de pescados y moluscos no obstante su distancia al mar, entre 23 y $25 \mathrm{~km}$. Predominan: anchovetas (Engraulis rigens), sardinas (Sardinop sagax), machas (Mesodesma donacium) y choros (Choromytilus chorus) (Shady, 2000:49-66; 2003:107-122; Béarez y Miranda, 2003:123-132). La ausencia de redes o instrumentos de pesca en la ciudad sugiere la adquisición de tales productos por medio del intercambio con poblaciones del litoral, como sus coetáneas de Bandurria y Áspero (Supe), donde se han encontrado anzuelos y redes, y con las cuales comparte elementos culturales.

Por otro lado, la abundante presencia en Caral de semillas de algodón (Gossypium barbadense) indica el especial énfasis que los habitantes del valle pusieron en ese cultivo, cuya fibra era demandada por los pobladores del litoral para la confección de las redes de pesca y de ropa. En el valle también cultivaron mates (Lagenaria siceraria), para la manufactura de los flotadores de las redes de pesca y de cuencos y vasos; $y$, fundamentalmente, plantas destinadas a su alimentación, como calabazas y zapallos (Cucurbita spp.), frijol (Phaseolus vulgaris), pallar (Phaseolus lunatus), achira (Canna edulis), camote (Ipomoea 

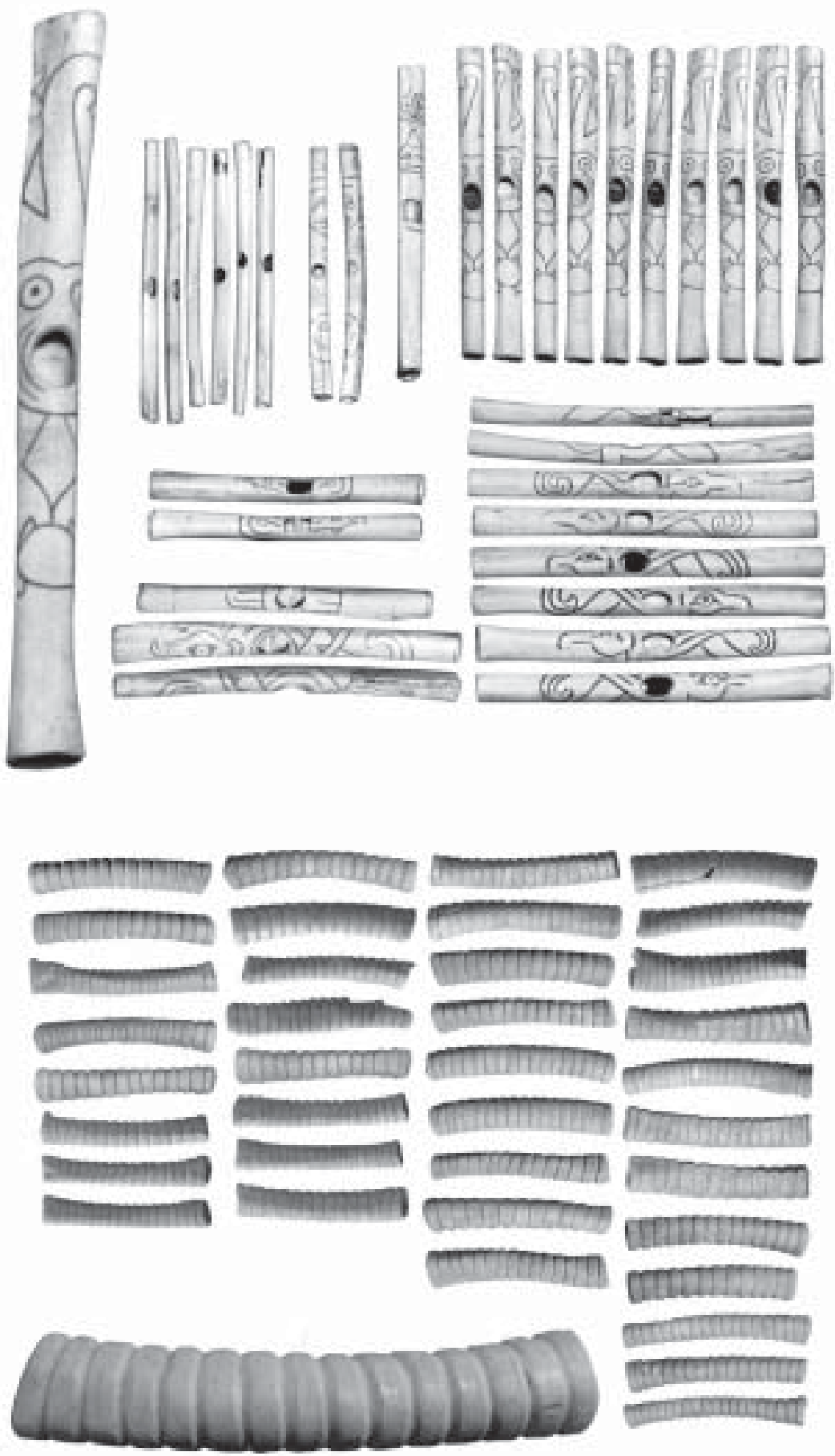

FIGURA 6 : Dos conjuntos musicales; a, Flautas traversas; b, cornetas. 
batatas), yuca (Manihot esculenta), pajuro (Erythrina edulis), maní (Arachis hypogaea), palta (Persea americana), guayaba (Psidium guajava), pacae (Inga feuillei), lúcuma (Pouteria lucuma), ají (Capsicum frutesiens). Se ha recuperado, asimismo, plantas como palillo (Campomanesia lineatifolia), achiote (Bixa orellana), huayruro (Ormosia sp.), tutumo (Crescentia cujete), lloque (Kageneckia lanceolata), probablemente llegadas de otras zonas; así como junco (Schoenoplectus sp.) y otras, recogidas de las zonas pantanosas del valle (Shady, 1999b:2-4; 2000b:49-66). El maíz (Zea maiz) aparece sólo en el período tardío y en poca cantidad.

La información sobre el patrón de asentamiento y las evidencias recuperadas de las excavaciones, en particular en las unidades domésticas, indican que la población de Supe residía en asentamientos nucleados, «pachacas», distribuidos tanto en el litoral como en el valle, con acceso a los recursos de uno de los mares más productivos del planeta, a las tierras del valle, mayormente llanas, de fácil riego con aguas del río y de los manantiales, a las zonas de humedales y lomas, que son todavía extensas y a la flora y fauna del monte ribereño. En esas condiciones se desarrolló una economía productiva, internamente complementaria, agrícolapesquera, articulada por el intercambio.

Los agricultores del valle producían plantas alimenticias e industriales, como camote, zapallo, frijol o algodón, mates y maderos; en cambio, los asentamientos de pescadores del litoral extraían preferentemente anchovetas y sardinas, que deshidrataban en grandes cantidades, además de moluscos y algas, entre otros. La productividad de ambos sectores económicos, la disponibilidad de excedentes y la interdependencia entre sus componentes ocupacionales: del algodón, mates y madera los pescadores para la confección de sus embarcaciones, redes de pesca, flotadores y remos, y de la proteína del recurso marino los agricultores, fomentaron un intenso intercambio interno entre pescadores y agricultores y generaron una esfera económica supracomunal. Esta actividad conducida por las autoridades de los asentamientos o «pachacas» habría beneficiado económicamente a éstas.

El hilado y la manufactura de tejidos de algodón le agregaron un valor adicional en beneficio de los productores del valle. Por otro lado, al intercambio interno se adicionó un intercambio externo, para cubrir la demanda de las autoridades, actividad que creció y se extendió a otras áreas costeñas y a las regiones de sierra y selva del área norcentral, de donde los funcionarios de Caral adquirieron bienes como Spondylus, madera, caracoles, plantas medicinales, fibras vegetales, piedras semipreciosas, pigmentos, etc. La conexión alcanzó a grupos de lugares distantes, como la costa del extremo norte del país o Ecuador, para la adquisición del preciado Spondylus, con el cual manufacturaron objetos de valor simbólico.

Aquellas y estas actividades favorecieron la acumulación de riqueza, el incremento de prestigio y la formación de clases sociales; y le permitieron a la sociedad de Supe captar en su beneficio los excedentes producidos en el área, así como 

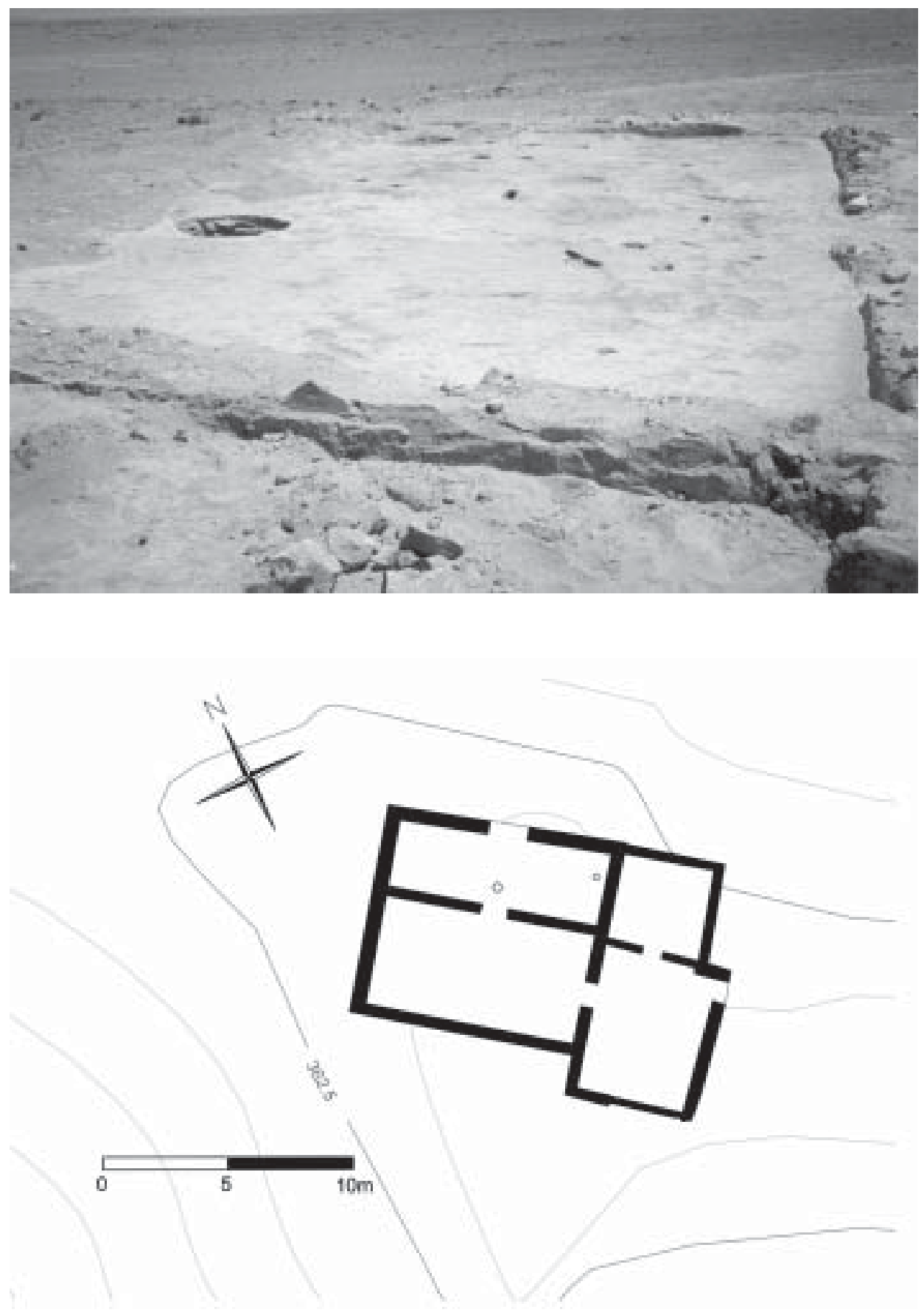

FIGURA 7 : Recintos usados como talleres de producción artesanal. 
fortalecer el poder de sus autoridades, que habrían iniciado un proceso de integración política, bajo la forma de un gobierno centralizado.

Estos excedentes se invirtieron en:

1. Obras de infraestructura económica, como la construcción de reservorios, canales de riego y su mantenimiento.

2. La construcción y permanente remodelación de los edificios públicos.

3. El mantenimiento de los funcionarios políticos, administrativos, religiosos.

4. El trabajo de especialistas dedicados a la producción de conocimientos en los campos de la astronomía, aritmética, geometría, medicina, agricultura y a su aplicación en la elaboración del calendario, en el diseño y construcción urbanos, en el acondicionamiento de los campos de cultivo y la administración de las aguas, etc.

\section{RELACIONES SOCIALES DE PRODUCCIÓN}

La comunidad o «pachaca» era la unidad básica de producción, y en el caso del valle, la encargada de habilitar periódicamente los canales de riego y de distribuir las tierras de cultivo, que eran de su propiedad entre las familias o ayllus, que la componían, para su cultivo y sustento. El trabajador pertenecía a una «pachaca» y a través de ella accedía al medio de producción. La «pachaca» congregaba a un número de unidades domésticas, linajes o ayllus, en torno a una porción de tierras regada por un sistema de canales, tenía sus propias autoridades y sus respectivos edificios públicos para fines multifuncionales, políticos, religiosos, económicos, administrativos, a la par que estaba articulada al sistema mayor del valle. El Estado integró a las «pachacas» de pescadores del litoral, de tejedores de juncos y esteras y de agricultores. Como hemos indicado, han sido identificados 18 asentamientos de «pachacas» a lo largo de los primeros $45 \mathrm{~km}$ del valle de Supe (Shady et al., 2000: 13-48).

\section{LA ORGANIZACIÓN SOCIAL, POLÍTICA Y LA FORMACIÓN DEL ESTADO}

Los centros urbanos o «pachacas» contienen varios conjuntos de unidades residenciales y edificios públicos, cuyas diversas características son indicadores de las distinciones sociales al interior de cada asentamiento así como entre asentamientos. En las «pachacas» se realizaba un conjunto de actividades para garantizar el autosostenimiento como también de los especialistas y autoridades. Estos dirigían y controlaban a la fuerza de trabajo para la realización de todo tipo de actividad, en base a una ideología que justificaba la inversión y la distribución de la riqueza producida.

La recurrencia de determinados elementos arquitectónicos y formas culturales así como la distinción social al interior de cada asentamiento y entre el conjunto 
de ellos indican la integración de estas comunidades autosuficientes o «pachacas» a un sistema mayor que mantuvo, sin embargo, las autonomías de gobierno.

La presencia de determinadas estructuras arquitectónicas, como el edificio escalonado o иshnu, la plataforma con 13 cubículos, los recintos con hornacinas, entre otros, que aparecen en Caral, continuarán como símbolos del poder político y religioso a lo largo del proceso cultural andino hasta el imperio inca.

En varios edificios de la ciudad se han encontrado entierros humanos, mayormente de niños, todos vinculados con determinados rituales. Los objetos asociados a estos entierros indican diferencias de estatus, que en el caso de los niños, de menos de dos años, eran adscritos. Un diferente acceso a los bienes de consumo y de prestigio revela, asimismo, a una sociedad con desigual distribución de la riqueza.

La desigualdad social se hace también notoria en los resultados alcanzados por los estudios de paleopatología de un individuo de 20 a 25 años, que fue muerto y enterrado contra su voluntad. El cadáver había sido depositado junto con la capa de tierra y piedras al enterrarse un atrio de la Pirámide Mayor. El cuerpo estaba desnudo con los brazos extendidos y cruzados en la espalda y no llevaba ninguna ofrenda. Los estudios indican que tuvo una salud precaria en su infancia (espongiohiperortosis, cibra orbitalia e hipoplasia del esmalte, además de una patología oral profusa) derivada de una dieta hipoproteica asociada a anemia crónica; padeció de osteoartritis precoz de la columna dorsal baja y lumbar, patología asociada a trauma crónico por motivos laborales como la carga de peso excesivo por tiempo prolongado (transportando materiales para la construcción y remodelación de los templos o para el comercio a largas distancias), así como de osteocondritis dissecans, lesiones en las articulaciones metatarso falángicas de ambos pies, patología que se da en varones jóvenes que esfuerzan mucho sus pies; murió como consecuencia de un traumatismo cráneo-encefálico frontal. El hallazgo de falanges en nichos del templo enterrado corrobora la hipótesis de sacrificio de este individuo, perteneciente a la clase trabajadora de la estratificada sociedad de Supe (Lombardi y García, 2004: 1-16).

\section{EL ROL DE LA RELIGIÓN}

Para algunos se requiere constatar que hubo un ejército o fuerza militar para probar la existencia de la forma política estatal. Pero en el estado inicial de la formación estatal tal control de la población no fue necesario; la religión era el instrumento de cohesión y de coerción de la población, de gran efectividad (Shady 1999a, b).

La ideología prestigiada por el Estado de Supe habría actuado como el nexo de cohesión más importante de los grupos sociales o «pachacas» que se encontraban bajo la dominación del gobierno centralizado; ellos habrían compartido dioses generales y representaciones simbólicas de preceptos religiosos y cosmológicos. Como indican algunos documentos coloniales sobre el área, dioses como Huari habrían 
enseñado a los pobladores a preparar sus chacras, trazar sus canales, sembrar las plantas, mejorar sus cosechas y a poner sus hitos en defensa de sus pertenencias. Al sol, a la luna, a la tierra y al agua, simbolizados con determinadas formas, había que rendir culto, hacer ritos propiciatorios y cumplir con el calendario de ceremonias, asociado con los trabajos en los edificios públicos, en las tierras de los dioses, $\mathrm{y}$ de quienes eran sus intermediarios.

\section{CONCLUSIONES}

1. El temprano desarrollo de la civilización de Supe se debió a la creciente complejización de los sistemas sociales que se consolidaban en las varias regiones del área norcentral. Todos habían alcanzado a producir excedentes y a tener un nivel de organización que les permitía cierta especialización laboral, la construcción de edificios públicos y su participación en redes de intercambio interregional

2. Las sociedades costeñas del área norcentral lograron significativos avances en el aprovechamiento de los recursos de la región alrededor de los 3000 a.C. Aplicaron nuevas tecnologías en la pesca, como las redes de algodón para la extracción masiva de anchovetas y sardinas, y en la agricultura, los canales de riego y la construcción de terrazas. Estas innovaciones incrementaron la productividad y fomentaron el intercambio de productos.

3. Los pescadores y agricultores de Supe a la par de su especialización laboral estuvieron integrados en un sistema económico complementario. Los pescadores dependían del algodón de los agricultores para la confección de las redes de pesca y los agricultores recibían a cambio pescado deshidratado.

4. El intercambio económico interno, local y regional primero, e interregional y a larga distancia después, benefició a los asentamientos ubicados en vías de comunicación y propició la acumulación desigual de riqueza y la formación de clases sociales.

5. La protección de los intereses de la clase enriquecida fomentó la integración de las comunidades o «pachacas» a un sistema político estatal. Su ámbito de manejo y control directo incluyó primero a las poblaciones de Supe, Pativilca, Fortaleza y Huaura pero su interacción y prestigio se extendieron por toda el área norcentral. 42 fechados radiocarbónicos han confirmado su antigüedad como la civilización más antigua del Perú y de América.

6. El sistema social de Supe se caracterizó por una división compleja del trabajo, con especialistas en actividades diversas a la de aquellos dedicados a la producción de bienes de subsistencia. Están los pescadores de anchovetas; los agricultores de algodón y mate; los artesanos; los constructores de las obras arquitectónicas; los artífices del calendario de actividades; las autoridades, etc.

7. El templo y las unidades domésticas de las autoridades fueron instituciones multifuncionales, para la conducción de las diversas actividades sociales, económicas, políticas, religiosas y para el ejercicio del poder sobre la población. 
8. Caral fue el centro urbano donde residieron autoridades, especialistas, funcionarios, artesanos y servidores.

9. El valle medio inferior de Supe fue la sede donde se asentó el primer gobierno del sistema central, alrededor de los 2600 a.C. La cuantiosa inversión de trabajo en obras monumentales y su permanente remodelación fueron sustentadas por la productividad del área, que el Estado prístino captó. La desigual distribución de la riqueza está indicada por la jerarquía de unos asentamientos sobre otros; la distinción entre unidades domésticas; el tratamiento diferenciado en los entierros de niños y de adultos.

10. El Estado usó a la religión como instrumento de cohesión y control social. A través de ella se garantizaba la reproducción de las condiciones materiales de vida pero se ejercía también sanción y castigo.

11. Caral ha sido el modelo de organización social que desarrollaron otras sociedades en períodos posteriores en el territorio del Perú.

\section{REFERENCIAS}

BÉAREZ, Philippe y Luis MirandA

2003 «Análisis arqueo-ictiológico del sector residencial del sitio arqueológico de CaralSupe, Costa Central del Perú». En La Ciudad Sagrada de Caral-Supe. Los orígenes de la civilización andina y la formación del Estado prístino en el antiguo Perú, editado por Ruth Shady y Carlos Leyva, pp. 123-132. Lima: PEACS/INC.

BONNIER, Elizabeth y Catherine ROZENBERG

1988 «Del santuario al caserío: acerca de la neolitización en la cordillera de los Andes Centrales». En Boletín del Instituto Francés de Estudios Andinos 16(2), Lima, pp. 23-40.

BURGER, Richard y Lucy SALAZAR-BURGER

1980 «Ritual and Religion at Huaricoto». En Archaeology 33 (6), pp. 26-32.

Duviols, Pierre

1986 Cultura andina y represión. Procesos y visitas de idolatrías y hechicerías en Cajatambo, Siglo XVII. Cusco: CBC.

ENGEL, Frederic

1987 De las begonias al maíz. Vida y producción en el antiguo Perú. Centro de Investigaciones de Zonas Áridas (CIZA), Lima.

FELDMAN, Robert

1980 Aspero, Peru: Architecture, Subsistence Economy and other Artifacts of a Preceramic Maritime Chiefdom. Tesis. Cambridge: Harvard University. 
1985 «Preceramic Corporate Architecture Evidences for the Development of Non Egalitarian Social Systems in Peru». En Early Ceremonial Architecture in the Andes editado por C. Donnan, pp. 71-92. Dumbarton Oaks Research Library and Collection, Washington D. C.

1987 «Architectural Evidence for the development of nonegalitarian social systems in Coastal Peru». En The Origins and development of the Andean State, editado por J. Hass, S. Pozorski y T. Pozorski, pp. 9-14. Cambridge University Press, Cambridge. «Preceramic Architecture and Subsistence Traditions». En Andean Past, vol. 3, pp. 67-86.

Fung, Rosa

1988 «The Late Preceramic and Initial Period». En Peruvian Prehistory editado por R. Keatinge, pp. 67-96. Cambridge: Cambridge University Press.

Grieder, T., A. Bueno, E. Smith y R. Malina

1988 La Galgada, Peru. A Preceramic Culture in Transition. Austin: University of Texas Press.

Hodder, Ian y Craig CESSFORD

2004 «Daily Practice and Social Memory at Catalhöyük». En American Antiquity, Vol. 69, No. 1, pp. 17-40.

IzUMI, Seiichi y Kazuo TeRADA

1972 Andes 4. Excavations at Kotosh, Peru, 1963 and 1966. Tokyo: University of Tokyo Press.

IzUMI, Seiichi y Toshihiko SonO

1963 Andes 2. Excavations at Kotosh, Peru. University of Tokyo Expedition, 1960. Tokyo.

KosoK, Paul

1965 Life, land and water in ancient Peru. New York: Long Island University Press.

LOMBARDI, Guido y Uriel GARCíA

2004 Estudio del esqueleto de la Pirámide Mayor de Caral. Pre print, Lima: PEACS. MOSELEY, Michael

1975 The Maritime Foundations of Andean Civilization. Menlo Park, California: Cummings Publishing Co.

Quilter, Jeffrey, B. OJeda, D. Pearsall, D. Sandweiss, J. Jones y E. Wing

1991 «The Subsistence Economy of El Paraiso, an Early Peruvian Site». En Science 251(4991), pp. 277-283.

RAYMOND, J. Scott

1981 «The Maritime Foundations of Andean Civilization: A Reconsideration of the Evidence». En American Antiquity 46(4), pp. 806-821.

SHADY, Ruth

1995 «a neolitización en los Andes Centrales y los orígenes del sedentarismo, la domesticación y la distinción social». En Saguntum, № 28, Universidad de Valencia, España, pp. 49-61.

1997a La Ciudad Sagrada de Caral-Supe en los albores de la civilización en el Perú. Lima: UNMSM. 
1997b «Caral. La Cité Ensevelie». En Archéologie, No 340, Francia, pp. 58-65.

1999a «La religión como forma de cohesión social y manejo político en los albores de la civilización en el Perú». En Boletín del Museo de Arqueología y Antropología, UNMSM, año 2, N ${ }^{\circ}$ 9, Lima, pp. 13-15.

1999b «Los orígenes de la civilización y la formación del Estado en el Perú: las evidencias arqueológicas de Caral-Supe (primera parte)». En Boletín del Museo de Arqueología y Antropología, UNMSM, año 2, Nº12, Lima, pp. 2-4.

2000a «Los orígenes de la civilización y la formación del Estado en el Perú: las evidencias arqueológicas de Caral-Supe (segunda parte)». En Boletín del Museo de Arqueología y Antropología, UNMSM, año 3, $\mathrm{N}^{\circ}$ 2, Lima, pp. 2-7.

2000 b «Sustento socioeconómico del Estado prístino de Supe-Perú: las evidencias de Caral-Supe». En Arqueología y Sociedad, №13, Museo de Arqueología y Antropología, UNMSM, Lima, pp. 49-66.

SHADY, Ruth y Miriam GoNZALES

2000 «Una tumba circular profanada de la Ciudad Sagrada de Caral-Supe». En Boletín del Museo de Arqueología y Antropología, UNMSM, año 3, Nº 5, Lima, pp. 2-9.

Shady, Ruth, C. Dolorier, F. Montesinos y L. CASAS

2000 «Los orígenes de la civilización en el Perú: el área norcentral y el valle de Supe durante el Arcaico Tardío». En Arqueología y Sociedad, N 13, MAA, UNMSM, Lima, pp. 13-48.

Shady, Ruth, M. Machacuay y R. Aramburú

2000 «La Plaza Circular del Templo Mayor de Caral: su presencia en Supe y en el área norcentral del Perú». En Boletín del Museo de Arqueología y Antropología, UNMSM, año 3, No 8, Lima, pp. 2-25.

SHADY, Ruth y Carlos LEYvA (eds.)

2003 La Ciudad Sagrada de Caral-Supe. Los orígenes de la civilización andina y la formación del Estado prístino en el antiguo Perú. Lima: PEACS/INC.

SHADY, Ruth

2004 «Caral-Supe, la civilización más antigua de Perú y de América». En Andean Archaeology III: North and South, William H. Isbell y Helaine Silverman, eds. (en imprenta).

WENDT, W. E.

1964 «Die prakeramische seidlung am Rio Seco, Peru». En Baessler Archiv 11(2): 225275.

Willey, G. R. y J. M. CoRbeTT

1954 Early Ancon and Early Supe Culture. Chavin Horizon Sites of the Central Peruvian Coast. New York: Columbia University Press. 
WiLliams, Carlos y Francisco Merino

1979 Inventario, catastro y delimitación del patrimonio arqueológico del valle de Supe. Lima: INC.

WILSON, David

1981 «Of Maize and Men: A Critique of the Maritime Hypothesis of State Origins on the Coast of Peru». En American Anthropologist 83, pp. 93-120.

Wright, Henry T. y Greg A. JoHNSON

1975 «Population, exchange and early state formation in southwestern Iran ». En American Anthropologist, 77, pp. 267-289.

ZECHENTER, Elzbieta

1988 Subsistence strategies in the Supe Valley of the Peruvian Central Coast during the Complex Preceramic and Initial Periods. Tesis. Los Angeles: University of California. 